\title{
EFEKTIVITAS PEMBELAJARAN DI LUAR JAM SEKOLAH TERHADAP PRESTASI BELAJAR ANAK DI SDN 07 MATARAM (Studi Kasus pada Siswa Kelas V di SDN 07 Mataram)
}

\author{
Sintayana Muhardini \\ Dosen PGSD Universitas Muhammadiyah Mataram \\ muhardsinta@gmail.com
}

\section{INFO ARTIKEL \\ Riwayat Artikel: \\ Diterima: $28-11-2017$ \\ Disetujui: 25 - 12 - 2017}

\section{Kata Kunci:}

\section{Efektifitas \\ Pembelajaran \\ 2. Prestasi belajar}

\begin{abstract}
ABSTRAK
Abstrak: Penelitian ini bertujuan untuk mengetahui efektifitas pembelajaran di luar jam sekolah terhadap prestasi belajar anak di SDN 07 Mataram, Jenis penelitian ini adalah penelitian kualitatif dengan menggunakan bebagai metode yaitu metode observasi, wawancara secara langsung ke lapangan. Hasill penelitian menunjukkan bahwa : (1) Pelaksanaan pembelajaran waktu di luar jam sekolah berjalan efektif, (2) prestasi anak setelah mengikuti pembelajaran yang diadakan diluar jam sekolah tergolong baik dan memuaskan. Dapat disimpulkan bahwa penerapan pelaksanaan pembelajaran di luar jam sekolah berjalan dengan efektif, pemanfaatan waktu luang siswa di laksanakan dengan konsep yang dan pengaturan waktu yang baik dan tidak terkesan memaksakan karena kegiatan ini dilaksanakan tidak setiap hari melainkan hanya dua hari dalam seminggu, perencanaan waktu dan penggunaan metode pembelajaran yang tepat sangat di perlukan sehingga guru di tuntut untuk bisa melakukan perencanaan waktu yang tepat dan menerapkan metode pembelajaran yang menarik agar pelaksanaan pembelajaran di uar jam sekolah dapat berjalan dengan efektif, siswa tidak merasa jenuh dan bosan sehingga minat belajar, semangat dan prestasi belajar siwa bisa meningkat.
\end{abstract}

\section{A. LATAR BELAKANG}

Dalam penyelenggaraan pendidikan di sekolah yang melibatkan guru sebagai pendidik dan siswa sebagai peserta didik, diwujudkan dengan adanya interaksi belajar mengajar atau proses pembelajaran. Dalam konteks penyelenggaraan ini, guru merencanakan kegiatan pengajarannya secara sistematis dan berpedoman pada seperangkat aturan dan rencana tentang pendidikan yang dikemas dalam bentuk kurikulum, yang meliputi seperangkat rencana dan pengaturan mengenai tujuan, isi dan bahan pelajaran serta cara yang digunakan sebagai pedoman penyelenggaraan kegiatan pembelajaran untuk mencapai tujuan pendidikan tertentu, dalam artian bahwa pembelajaran yang baik bersifat menyeluruh dalam melaksanakan dan mencakup berbagai aspek baik aspek kognitif, afektif, maupun psikomotorik, sehingga dalam pengukuran tingkat keberhasilannya selain dilihat dari segi kuantitas juga dari kualitas yang telah dilakukan di sekolahsekolah.
Disamping itu perencanaan waktu sangat krusial dalam mempengaruhi pencapaian target pembelajaran. Ketersediaan waktu erat kaitannya dengan keberhasilan siswa dalam memahami materi pelajaran. Bagaimana waktu yang cukup bisa membuat siswa menguasai lebih dalam sebuah materi yang diajarkan, dan berapa lama waktu yang dibutuhkan oleh siswa untuk memahami pelajaran dengan inteligensi yang berbeda-beda. Sering karena terbatasnya waktu siswa dipaksa untuk mengerjakan sekian banyak tugas instruksional dalam waktu yang sempit. Hal ini disebabkan karena satu kenyataan bahwa bahan pengajaran di kurikulum kita terlalu overload. Bagi siswa sendiri, kejar materi dan tugas yang overload, merupakan suatu ketakutan. Bagaimana mereka bisa memahami materi yang begitu banyak dalam waktu singkat sehingga menyebabkan kejenuhan berpikir dan belajar, serta secara bersamaan bagaimana cara menyelesaikan setumpuk tugas untuk memenuhi kolom penilaian yang menjadi pegangan guru dalam waktu yang 
juga mendesak. Sebagai akibat, ketakutan akan penurunan prestasipun muncul.

Perencanaan pembelajaran perlu dipikirkan dengan baik oleh guru, Sabirin menjelaskan pada hakikatnya perencanaan pembelajaran adalah suatu rangkaian proses kegiatan menyiapkan keputusan mengenai apa yang diharapkan terjadi (waktu, peristiwa, keadaan, suasana, dan sebagainya) dan apa yang akan dilakukan[1] . Perencanaan pembelajaran yang melingkupi materi, strategi, dan waktu yang diperkirakan sudah efisien mungkin akan menjadi di luar dugaan dalam proses belajarmengajar. Akibatnya kebanyakan guru mengejar target materi dengan menumpuk tugas siswa atau kejar materi dengan mengajarkan sebanyak-banyaknya topik dalam sekali pertemuan yang mengakibatkan siswa tidak memiliki waktu untuk memikirkan dan mencoba mencerna pelajaran yang diberikan lebih mendalam. Resikonya siswa tidak menguasai materi pelajaran dengan baik dan tidak sempat untuk mengerjakan tugas yang diberikan dengan hasil maksimal, sehingga target pembelajaran untuk memahamkan siswa dan menjadikan siswa cerdas tidak tercapai.

Guru sebagai promotor dalam kegiatan belajarmengajar harus mampu mempertimbangkan waktu pembelajaran. Hal ini meliputi berapa banyak waktu yang diperlukan untuk tatap muka di kelas dan waktu tambahan yang dibutuhkan siswa di luar sekolah untuk mengerjakan berbagai tugas instruksional. Richard I. Arends mengungkapkan bahwa di luar sekolah, sejumlah siswa ditemukan menggunakan banyak proporsi waktu mereka bukan untuk kegiatan akademik melainkan untuk aktifitas rumahan[2]. Di kelas pun siswa sering berpacu dengan waktu untuk menyerap pelajaran secepat mungkin. Padahal siswa yang memiliki kelas dengan alokasi waktu yang lebih banyak untuk mengerjakan tugas akademik bisa meraih prestasi yang lebih baik dalam bidang matematika dan membaca.

Abdullah Pandang berpendapat bahwa tidak ada satu cara yang paling efektif untuk mengelola waktu terbaik dalam kegiatan belajar-mengajar. Yang paling baik adalah guru ataupun siswa mencobakan dan menjadwalkan waktu sesuai pola kerja sendiri hingga merasa nyaman pada pengelolaan waktu tersebut[3], Sehingga dalam perencanaan pembelajaran seorang guru haruslah berpikir lebih keras bagaimana upaya pengefeektifan waktu.

Setelah peneliti melakukan survei ternyata di SDN 07 Mataram menerapkan sebuah sistem belajar diluar jam sekolah dengan kata lain anak-anak mendapatkan pelajaran tambahan setelah jam sekolah berakhir sehingga anak-anak tersebut pulang sekolah tidak seperti jam-jam sekolah biasa, mereka pulang sekolah pukul 15.00 Wita, karena ada jam tambahan dimulai dari jam 13.00-15.00 Wita, pembelajaran tambahan ini hanya diberlakukan untuk kelas III sampai kelas VI, namun dalam penelitian ini peneliti hanya fokus meneliti kepada kelas VC.

\section{B. METODE PENELITIAN}

Sesuai dengan karakter permasalahan dan tujuan yang ingin dicapai maka penelitian ini menggunakan pendekatan kualitatif. Sehingga keseluruhan proses penelitian diupayakan untuk mentaati konsep dasar dan aturan penelitian kualitatif dengan model deskriptif. Dalam penelitian kualitatif, yang menjadi instrumen adalah peneliti itu sendiri. Penelitian kualitatif sebagai human instrument, berfungsi menetapkan fokus penelitian, memilih informan sebagai sumber data, melakukan pengumpulan data, menilai kualitas data, analisis data, menafsirkan data dan membuat kesimpulan atas temuannya seperti yang di kemukakan oleh Lincoln and Guba menyatakan:

The instrument of choice in naturalistic inquiry is the human. We shall see that other forms of instrumentation may be used in later phases of the inquiry, but the human is the initial and continuing mainstay. But if the human instrument has been used extensively in earlier stages of inquiry, so that an instrument can be contracted that is grounded in the data that the human instrument has product ${ }^{[4]}$.

Dalam penelitian kualitatif, tidak ada pilihan lain daripada menjadikan manusia sebagai instrumen penelitian utama. Alasannya ialah bahwa segala sesuatunya belum mempunyai bentuk yang pasti. Dalam keadaan yang serba tidak pasti dan tidak jelas itu, tidak ada pilihan lain dan hanya peneliti itu sendiri sebagai alat satu-satunya yang dapat mencapainya. Bila dilihat dari sumber datanya, maka pengumpulan data dapat menggunakan sumber primer dan sumber sekunder. Sumber primer adalah sumber data yang langsung memberikan data kepada pengumpul data, dan sumber sekunder merupakan sumber yang tidak langsung memberikan data kepada pengumpul data, misalnya lewat orang lain, atau lewat dokumen. Selanjutnya, jika dilihat dari segi cara atau teknik pengumpulan data, maka dapat dilakukan dengan observasi (pengamatan), interview (wawancara), dokumentasi dan gabungan ketigannya..

\section{HASIL DAN PEMBAHASAN}

Penelitian ini dilaksanakan di SDN 7 Mataram yang beralamatkan di jalan Airlangga nomor 7 Mataram. Dimana SDN 7 Mataram ini terletak sebelah utara SMPN 13 dan sebelah selatan penjahit Simpatik. 
Berikut ini gambar lokasi sekolah.

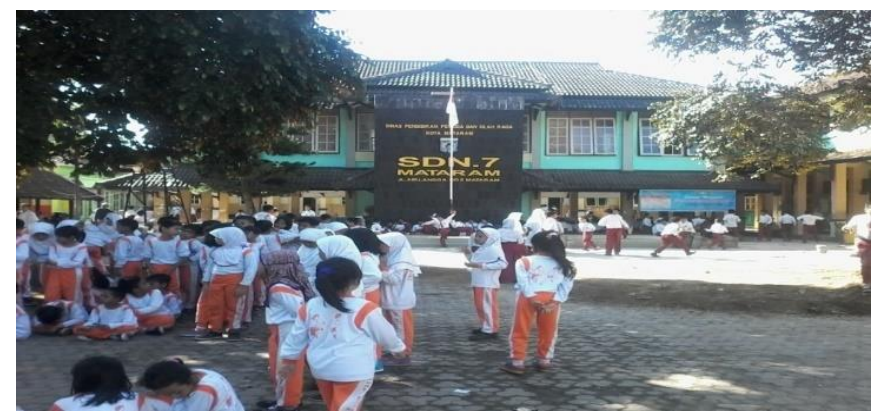

Proses pembelajaran yang dilakukan di SDN 7 Mataram khususnya kelas VC memiliki perbedaan dengan kebanyakan sekolah lain, di SDN 7 Mataram menerapkan pembelajaran di luar jam sekolah, adapun jadwal pelaksanaan pembelajaran di luar jam sekolah yang diadakan di SDN 7 Mataram kelas VC menurut Siti Hawa (wali kelas) dilakukan pada siang hari setiap hari senin dan selasa, setelah jam pulang sekolah samapai pukul 15.00 WITA. Pelaksanaan pembelajaran di luar jam sekolah merupakan salah satu praktik yang dalam upaya mengeefektifkan waktu pembelajaran siswa agar tujuan dan kompetensi yang diharapkan dapat tercapai. Jika kita lihat dari sudut pandang kebosanan siswa maka pada dasarnya semua orang tidak menghendaki kebosanan dalam hidupnya, demikian pula dalam proses pembelajaran, yang menjadi ketakutan adalah apabila pelaksanaan ini menimbulkan kebosanan dan kejenuhan belajar pada siswa, apa yang harus di lakukan agar penerapan pembelajaran di luar jam sekolah tidak berdampak buruk bahkan terkesan memaksakan dan siasia, maka kuncinya tetntu ada pada guru. Guru harus bisa menciptakan kondisi pembelajaran yang menyenangkan dengan menggunakan ragam teknik pembelajaran agar bisa tetap membangun semangat siswa sehingga tidak ada celah untuk munculkannya kebosannan dan kejunahan pada siswa. Tidak bisa dipungkiri jika guru tidak menggunakan metode pembelajaran yang tepat pada saat pembelajaran maka akan membosankan siswa. Apabila siswa merasa bosan dalam belajar maka akibatnya perhatian siswa akan berkurang. Menurut Hariyono (dalam Ervan Dwi Putra, 2011) mengatakan bahwa metode mengajar yang mengandalkan ceramah murni seyogyanya diminimalkan, daripada waktu habis digunakan untuk bercerita (ceramah) pendidik yang kadangkala menjenuhkan, seyogyanya memberi kesempatan peserta didik untuk berdiskusi, melanjutkan studi lapangan, pencarian dan penemuan, sosiodrama atau aktivitas lain yang memberi peluang pada peserta didik belajar lebih jauh.

Adapun tahapan pelakasanaan pembelajaran yang di lakukan tidak berbeda dengan pelasaanaan pembelajaran pada umumnya, Berikut ini tahapan proses pembelajaran yang dilakukan:
1. Kegiatan pra pembelajaran pada tahapan ini guru masuk kelas pukul 01.00 setelah jam pulang sekolah siswa dan guru melakukan shalat zuhur bersama kemudian diberikan kesempatan untuk makan siang agar para siswa memiliki tenaga yang cukup untuk melanjutkan kegiatan pembelajaran.

2. Menciptakan kondisi awal pembelajaran, pada tahapan ini guru mengkondisikan kelas setelah siswa melkukan kegiatan pra pembelajaran, guru dan siswa mulai menata kembali posisi duduk dan menyiapkan alat tulis dan yang terpenting adalah mengecek kehadiran siswa agar guru mengetahui siswa yang tidak mengikuti pembeljaran pada saat itu sehingga ada tindak lanjut yang bisa dilakukan guru untuk selanjutnya.

3. Melaksanakan kegiatan apersepsi atau melaksanakan tes awal, kegiatan ini dimaksudkan agar guru mengetahui sejauh mana siswa memahami materi pelajaran yang akan dilakukan, dan agar siswa bisa menggali pengetahuannya terhadap materi yang disampaikan berdasarkan pengetahuan awal yang dimiliki.

4. Memberitahukan tujuan atau garis besar materi dan kemampuan yang akan dipelajari

5. Menyampaikan alternatif kegiatan belajar yang akan ditempuh siswa, untuk tahap ini guru menyapaikan secara umum metode yang digunakan atau memeberitahu ragam kegiatan yang akan ditempuh pada saat pembelajaran hal ini dimasudkan agar siswa termotivasi dan menyiapkan diri dengan semangat untuk memulai pembelajaran.

6. Membahas materi/menyajikan bahan pelajaran, untuk di tahapan ini adalah inti dari kegiatan pembelajaran bahwa peran dan strategi pembelajaran yang dirancang guru digunakan dan dimaksimalkan pada tahapan pembahasan materi, berdasarkan pengamatan di lapangan guru menggunakan pembelajaran dengan teknik diskusi kelompok yang diselingi dengan permainan, sehingga pada saat pembelajaran berlangsung siswa menjadi tidak mengantuk dan tidak bosan.

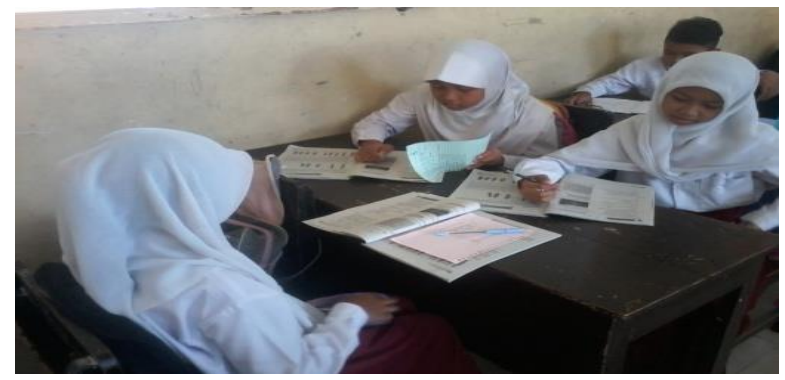




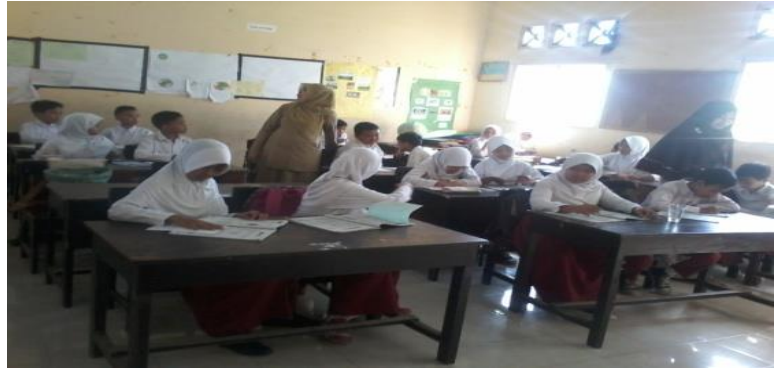

7. Menyimpulkan pelajaran, ditahapan akhir pembelajaran guru merangkum dan menyimpulkan pembelajaran secara bersama-sama dan menutup pembelajaran serta mengingatkan untuk mengulang pelajajaran hari itu di rumah masing-masing.

Rangkaian kegiatan di atas merupakan tahapan pembelajaran yang dilakukan oleh guru kelas selama kegiatan pembelajaran di luar jam sekolah, jadi dapat disimpulkan bahwa kegiatan yang dilakukan tidak jauh berbeda dengan pembelajaran di kelas pada umumnya, hanya saja sangat ditekankan pada kemampuan guru didalam pengelolaan kelas agar lebih menyenangkan dan menimbulkan semangat untuk para siswa, karena tidak bisa dipungkiri bahwa pembelajaran di luar jam sekolah membutuhkan konsentrasi yang lebih dan kondisi yang menyenangkan agar tidak menimbulkan kebosanan dan kejenuhan pada saat berlangsungnya proses pembelajaran.

Berkaitan dengan prestasi yang diperloeh siswa maka dari data dan informasi yang peneliti peroleh menunjukkan bahwa prestasi siswa secara keseluruhan tergolong baik dan memuaskan, dari hasil belajar setiap semester menunjukkan bahwa siswa-siswa dalam hal ini siswa kelas VC sebagai sampel penelitian memiliki nilai rapor yang jauh melampaui KKM, dan berkaitan dengan prestasi di luar sekolah berdasarkan hasilwawancara kami dengan wali kelas menjukkan bahwa salah satu siwa kelas VC bisa mewakilkan sekolah dalam olimpiade matematika tingkat nasional, kreatifitas siswa juga sangat terlihat di kelas bahkan hasil karya siswa terpajang di setiap sudut ruangan, banyak hasil karya yang diciptakan sendiri oleh siswa mulai dari mata pelajaran sain hingga kesenian dan kerjainan tangan, berikut ini beberapa data yang kami peroleh mengenai presatasi dan kreatifitas para siswa kelas VC.
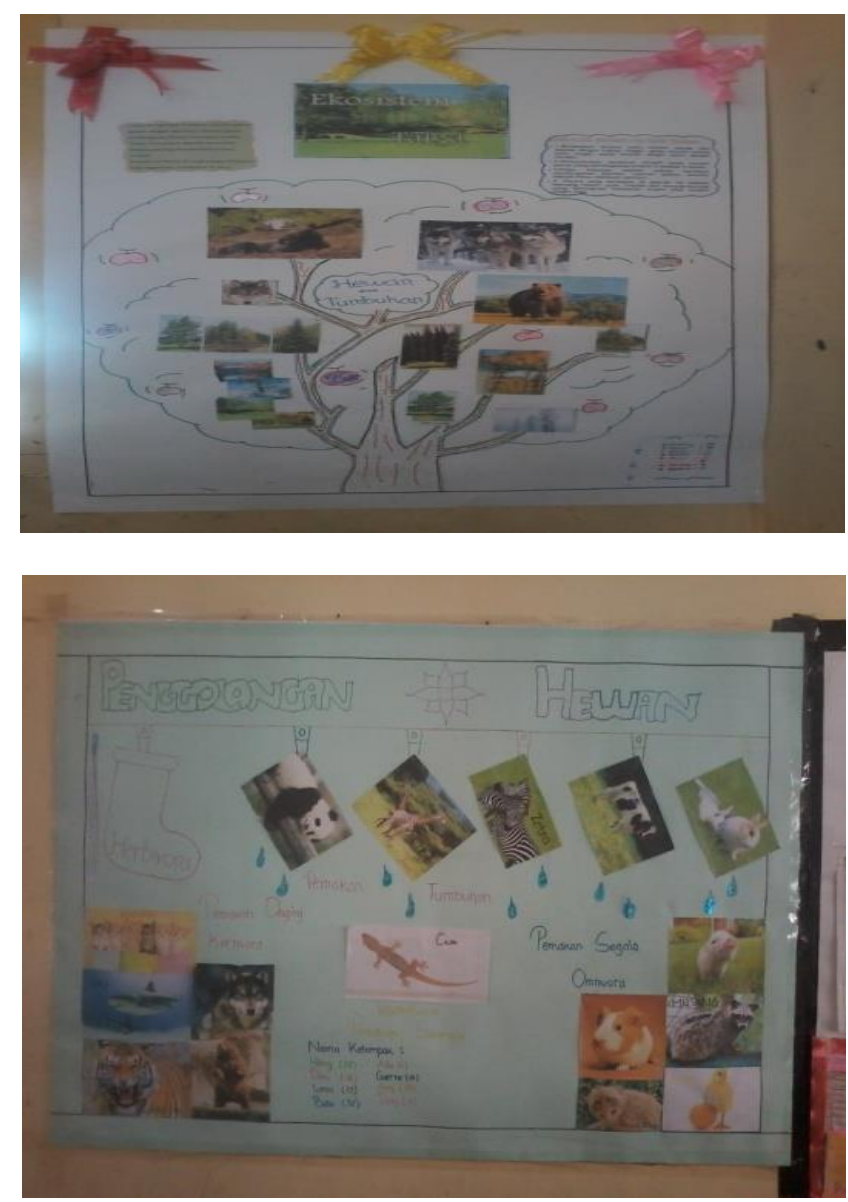

a. Gambar pajangan hasil karya siswa

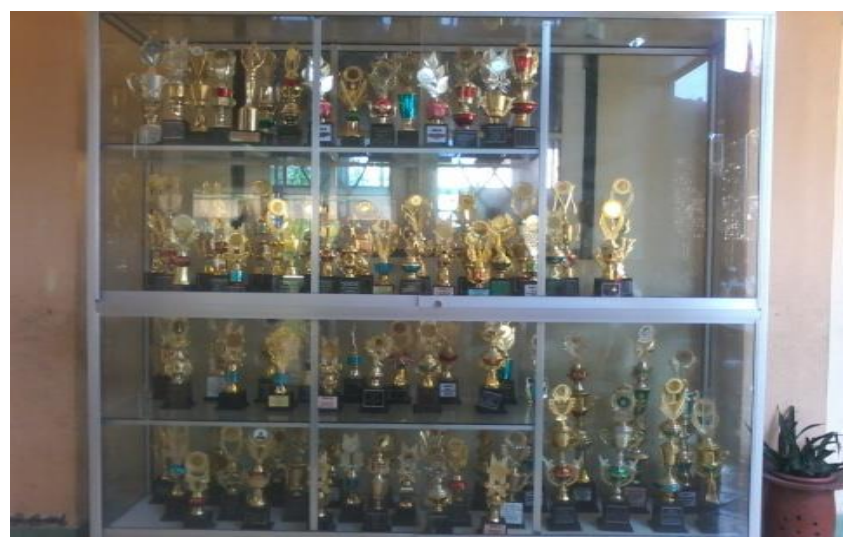

b. Beragam piala yang di peroleh

Dari banyaknya bukti fisik tentang prestasi berupa nilai rapot yang memuaskan dan ragam kreatifitas siswa yang ditemukan maka dapat disimpulkan bahwa prestasi siswa kelas VC yang ada di SDN 7 Mataram tidak mengecewakan, sehingga usaha yang dilakukan oleh guru dan pihak sekolah sudah efektif terutama dalam menerapkan pembelajaran di luar jam sekolah yang secara konsisten terus dilakukan artinya bahwa tingkat keberhasilan dari pelakasanaan ini sudah terlihat sebagai salah satu indikator yang memberikan kontribusi terhadap prestasi siswa.. 


\section{SIMPULAN DAN SARAN}

Berdasarkan analisis dan obeservasi lapangan yang dilaukan, maka dalam penelitian ini diperoleh kesimpulan bahwa penerapan pelaksanaan pembelajaran di luar jam sekolah berjalan dengan efektif, pemanfaatan waktu luang siswa di laksanakan dengan konsep yang dan pengaturan waktu yang baik dan tidak terkesan memaksakan karena kegiatan ini dilaksanakan tidak setiap hari melainkan hanya dua hari dalam seminggu, perencanaan waktu dan penggunaan metode pembelajaran yang tepat sangat di perlukan sehingga guru di tuntut untuk bisa melakukan perencanaan waktu yang tepat dan menerapkan metode pembelajaran yang menarik agar pelaksanaan pembelajaran di uar jam sekolah dapat berjalan dengan efektif, siswa tidak merasa jenuh dan bosan sehingga minat belajar, semangat dan prestasi belajar siwa bisa meningkat.

Berdasarkan kesimpulan, diajukan beberapa saran yang dapat dipertimbangkan dalam peningkatan pelaksanaan pembelajaran di luar jam sekolah: (1) Untuk meningkatkan hasil belajar yang maksimal, disarankan kepada guru untuk menggunakan teknik pembelajaran yang menarik dan menyenangkan, jangan menggunakan metode pembelajaran yang monoton yang akan menimbulkan kebosanan siswa; (5) Bagi peneliti lain disarankan mengadakan penelitian sejenis dengan sampel yang lebih banyak yang terdiri dari beberapa sekolah untuk melihat seberapa besar kefektifan pembelajaran di luar jam sekolah jika diterapkan secara menyeluruh.

\section{DAFTAR RUJUKAN}

[1] Richard. I. Arends, Educational Psychology, New York: The McGraw Hill, Inc., 2004

[2] Santrock, John W, Educational Psychology, New York: The McGraw Hill, Inc., 2004

[3] Norman K, Handbook of Qualitative Research

[4] Sabirin, Educational Psychology, New York: The McGraw Hill, Inc., 2004

[5] Sugiyono. Metode Penelitian Pendidikan Pendekatan Kualitatif, Kuantitatif, dan $R \& D$. Bandung: Alfabeta. 2010 